\title{
Alternative reagents to antibodies in imaging applications
}

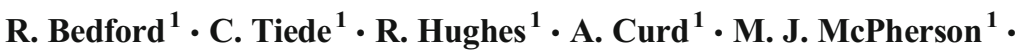 \\ Michelle Peckham $^{1} \cdot$ Darren C. Tomlinson ${ }^{1}$
}

Received: 26 June 2017 / Accepted: 6 July 2017 / Published online: 27 July 2017

(C) The Author(s) 2017. This article is an open access publication

\begin{abstract}
Antibodies have been indispensable tools in molecular biology, biochemistry and medical research. However, a number of issues surrounding validation, specificity and batch variation of commercially available antibodies have prompted research groups to develop novel non-antibody binding reagents. The ability to select highly specific monoclonal nonantibody binding proteins without the need for animals, the ease of production and the ability to site-directly label has enabled a wide variety of applications to be tested, including imaging. In this review, we discuss the success of a number of non-antibody reagents in imaging applications, including the recently reported Affimer.
\end{abstract}

Keywords Affimer · Adhiron · DARPin · Monobody · Imaging $\cdot$ Super-resolution

\section{Introduction}

Antibodies raised against a protein of interest have been the main tool used to investigate temporal and spatial protein expression, localisation and behaviour, with immunoglobulin $\mathrm{G}$ (IgG) being the most commonly used isotype. In bio-imaging, antibodies have been widely used in a number of techniques,

This article is part of a Special Issue on 'IUPAB Edinburgh Congress' edited by Damien Hall.

Michelle Peckham

m.peckham@leeds.ac.uk

Darren C. Tomlinson

d.c.tomlinson@leeds.ac.uk

1 School of Molecular and Cellular Biology, Astbury Centre for Structural and Molecular Biology, University of Leeds, Leeds, UK including immunofluorescence microscopy, immunohistochemistry, flow cytometry and immuno-electron microscopy. They are also used in many other research applications, such as immunoprecipitation, enzyme-linked immunosorbent assays and western blotting. The ground-breaking work of Kohler and Milstein in 1975, which resulted in the production of monoclonal antibodies (Kohler and Milstein 1975), has led to the use of these antibodies in treating patients. This began with the licencing of orthoclone OKT3®, a monoclonal antibody for the prevention of tissue rejection in cases of acute kidney transplantation (Starzl and Fung 1986). By 2014, 47 therapeutic-based monoclonal antibody treatments had been approved for use in the USA or Europe, generating almost US $\$ 100$ billion for the pharmaceutical industry (Ecker et al. 2015).

Despite this success, the generation and validation of antibodies, particularly for research applications, remains challenging, leading to growing concern about the potential for substantial waste of research funds on 'bad' antibodies (Taussig et al. 2007; Bordeaux et al. 2010, Bradbury and Pluckthun 2015) and the waste of animals in producing these reagents.

Recent advances have enabled the production of recombinant antibody fragments in Escherichia coli (Fig. 1), allowing a renewable source of reagent and thereby overcoming many issues of batch-to-batch variation commonly observed in animal-produced antibodies. For research purposes, the most commonly used fragments are the fragment of antigen binding (Fab) (Better et al. 1988) and single-chain fragment of variability ( $\mathrm{ScFv}$ ) (Skerra and Pluckthun 1988; Nelson and Reichert 2009). These smaller antibody-derived fragments have the advantages that they can be selected in vitro using a display technology as well as being produced in E. coli (Holliger and Hudson 2005; Nelson and Reichert 2009). 
Fig. 1 Examples of immunoglobulin $\mathrm{G}(\operatorname{Ig} G)$ and non-IgG-based binding reagents developed for use as research tools. One of the major advantages provided by the many IgG alternatives is their smaller size, as demonstrated by the IgG scale bars with all alternative reagents compared to scale. IgGbased reagents include the fragmented versions, fragment of antigen binding $(F a b)$ and singlechain fragment of variability $(S c F v)$ as well as the reformatted Camelid IgG (Nanobody). NonIgG-based reagents [Designed Ankyrin Repeat Proteins (DARPins), Monobodies, Anticalins, Affibodies] demonstrate even smaller sizes, with Affibodies approaching $1 \mathrm{~nm}$ in diameter compared to the $10-\mathrm{nm}$ diameter measured by the $\mathrm{IgG}$ antigen-binding region. PyMOL (Schrödinger, LLC, New York, NY) and KeyNote (Apple Inc., Cupertin, CA) were used to create the images

\section{IgG-based reagents}

$\operatorname{lgG}(1 \mathrm{HZH})$

$\mathrm{Fab}(4 \mathrm{FQH})$

$\mathrm{ScFv}(3 \mathrm{H} 3 \mathrm{~B})$

Nanobody (3OGO)
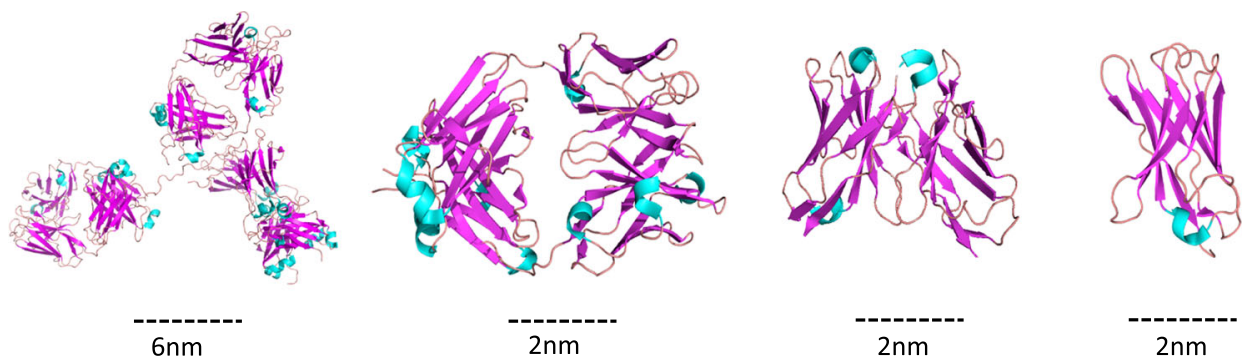

Non-IgG-based reagents

DARPin (4YDY)

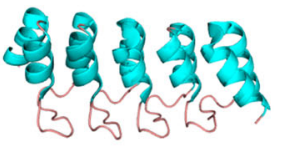

$2 n m$

Affibody (3MZW)

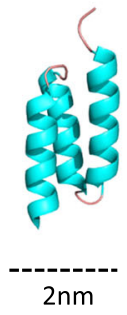

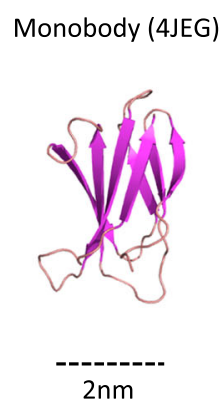

Affimer Type I (1NB5)

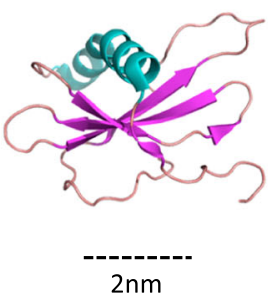

Anticalin (4GH7)

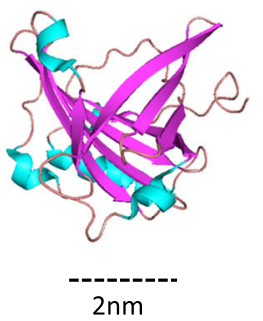

Affimer Type II (4N6T)

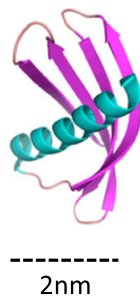

More recently, the IgG antibodies from the familyCamelidae have also been exploited. These antibodies do not contain any light chains, and the heavy chain only contains a single antigen-binding variable domain $\left(\mathrm{V}_{\mathrm{H}} \mathrm{H}\right)$ (Hamers-Casterman et al. 1993; Muyldermans 2001). The $\mathrm{V}_{\mathrm{H}} \mathrm{H}$, originally referred to as a heavy chain antibody (HCAb), is now known as a single-domain antibody or, more commonly, as a Nanobody (Fig. 1) (Nguyen et al. 2001; Daley et al. 2010). It has been developed for potential therapeutic use by Ablynx (Gent, Belgium). Nanobodies are highly stable, monomeric and smaller than the variable domain $\left(\mathrm{V}_{\mathrm{H}}\right)$ of classical antibodies. Importantly, they can be recombinantly produced and purified using $E$. coli to allow large amounts of pure antibody fragment to be generated. Currently, most Nanobodies are still generated using immunisation of Camelidae, followed by reformatting of the $\mathrm{V}_{\mathrm{H}} \mathrm{H}$ region of the cognate $\mathrm{HCAb}$ and further screening by traditional phage display (Nguyen et al. 2001).
As an alternative to antibodies, a number of nonimmunoglobulin binding reagents have now been developed, generally through adaptation of a naturally occurring protein or protein domain (Fig. 1). Importantly, all of these reagents are derived from synthetic libraries that allow identification of binding reagents without the use of animals. A potential disadvantage of this approach is that the ability to isolate useful reagents is dependent on the design, size, quality and display format of the library screened. However, important advantages are that these alternative binding reagents can all be produced recombinantly and that they are generally much smaller and more stable than antibodies. Whilst such nonantibody proteins have been reviewed in depth elsewhere (Hey et al. 2005; Skerra 2007; Skrlec et al. 2015; Simeon and Chen 2017), some of the more common reagents will be briefly discussed here (Fig. 1). These include Designed Ankyrin Repeat Proteins (DARPins), Monobodies, Anticalins, Affibodies and more recently Adhirons/Affimers. 
DARPins generally contain three to four tightly packed repeats of approximately 33 amino acid residues, with each repeat containing a $\beta$-turn and two anti-parallel $\alpha$-helices (Kawe et al. 2006). This rigid framework provides protein stability whilst enabling the presentation of variable regions, normally comprising six amino acid residues per repeat, for target recognition. Whilst the imaging applications of DARPins will be discussed in detail below, it is worth highlighting the development of a vascular endothelial growth factor (VEGF) A-specific DARPin for the treatment of macular degeneration (Stahl et al. 2013) that has recently entered phase III clinical trials (Molecular Partners AG, Zurich, Switzerland).

Monobodies are based on the fibronectin type III domain (Koide et al. 1998). This domain adopts a $\beta$-sandwich structure composed of seven $\beta$-sheets and contains three exposed loops available for target recognition. There are two Monobody libraries that diversify amino acids at different positions in the scaffold. Whilst the original libraries diversified amino acids within the loop regions, the secondgeneration library also diversifies a segment of the $\beta$-sheet. (Koide et al. 1998, 2012). This 'side and loop' diversification enables presentation of a concave binding surface, as opposed to the more usual flat or convex paratope of Monobodies. These different binding conformations increase the range of targets available for selection with those involved in proteinprotein interactions favoured by this 'side and loop' library (Wojcik et al. 2016).

Anticalins are derived from the lipocalin scaffold (Vogt and Skerra 2004). They contain eight anti-parallel $\beta$-strands that form a conserved $\beta$-barrel, attached to an adjacent $\alpha$-helix. The $\beta$-barrel provides target recognition by supporting four solvent-exposed loops (Gebauer and Skerra 2012). These reagents are derived from the human lipocalin protein family and as a consequence have low immunogenicity [Pieris AG (Freising, Germany) and AlgoNomics NV (Gent, Belgium), 2006]. An anti-hepcidin Anticalin is already in phase I clinical trials for the treatment of anaemia (Moebius et al. 2015).

Affibodies, based on the B-domain of staphylococcal protein $\mathrm{A}$, adopt a folded $\alpha$-helical structure that provides Affibodies with their stability (Nord et al. 1997). Further efforts to improve the innate stability of the B-domain led to a mutated 'Z-domain', with the ability of Affibodies to recognise a variety of targets through the randomisation of amino acid residues in the first two helices. This is the region of the protein that binds the $\mathrm{Fc}$ region of $\mathrm{IgG}$ in protein $\mathrm{A}$ (Lofblom et al. 2010).

Affimers can be classified as type I and type II based on their scaffold of either the human stefin A protein (Hoffmann et al. 2010) or consensus plant phytocystatin protein, respectively (Tiede et al. 2014). Both types contain four $\beta$-sheets and an $\alpha$-helix. The binding region is generated from sequences in two variable loops presented between pairs of $\beta$-sheets.
Affimers have been raised against a diverse set of targets, thereby demonstrating their utility in many different molecular biology applications, including those related to bioimaging (Fisher et al. 2015; Kyle et al. 2015; Raina et al. 2015; Sharma et al. 2016; Arrata et al. 2017; Koutsoumpeli et al. 2017; Tiede et al. 2017; Wang et al. 2017b).

Whilst non-antibody binding proteins were originally generated as simple affinity reagents, their ability to bind functional surfaces of target proteins has fast-tracked their use as therapeutic reagents (Roovers et al. 2007; Tamaskovic et al. 2012; Sha et al. 2017). Their small size (Fig. 1), specificity and stability have also proven important in exploiting them as imaging tools, particularly for use in 'super-resolution' imaging. The bio-imaging applications of these reagents are described in more detail below.

\section{Binding reagents for use as imaging tools}

\section{Detecting cancer biomarkers using antibody alternatives}

Although a large repertoire of antibodies are available for the detection of cancer biomarkers in tissues (Bouchelouche et al. 2010; Wang et al. 2013; Howat et al. 2014), the beneficial properties of alternative non-antibody reagents, particularly their specificity and ease of production, has prompted a number of groups to investigate their use in this application (Orlova et al. 2007; Goldstein et al. 2015; Van Audenhove and Gettemans 2016).

The human epidermal growth factor receptor 2 oncogene (HER-2) drives a number of oncogenic processes, including proliferation and invasion (Slamon et al. 1987). Clinically, the detection of HER-2 not only provides a prognostic prediction but also guides therapeutic options with Trastuzumab, a monoclonal antibody able to treat HER-2 over-expressing cancer cells (Vogel et al. 2002; Seidman et al. 2008). The importance of detecting HER-2 in tissue biopsies has prompted novel methods to be developed to detect this biomarker. A highly specific DARPin has been isolated for use in immunohistochemical applications for the detection of HER2 , with results proving to be as reliable, but with improved specificity, over a U.S. Federal Food and Drug Administration (FDA)-approved antibody (4B5) (van der Vegt et al. 2009) for the detection of HER-2 in human tissues (Theurillat et al. 2010). An anti-HER-2 Affibody is also currently being commercially developed by Abcam (Cambridge, UK) for use in immunohistochemistry. It is also worth noting that HER-2specific Nanobody reagents have been developed for use in tissue staining, although these are mainly used as molecular imaging tools in vivo and will be discussed in the next section of this review (Vaneycken et al. 2011; Xavier et al. 2013).

Nanobodies have, however, been raised against a number of other cancer biomarkers for use in tissue staining. A 
nanobody targeting the antigen ADP-ribosyltransferase ARTC2.2 has been used for the histological staining of ARTC2-positive xenografts for the validation of in vivo imaging results post-sacrifice of the test rodent (Bannas et al. 2015). The results demonstrated that in comparison to an anti-ARTC2 antibody, a strong and homogenous staining of cells was observed in positive tumour sections in comparison to a much weaker and non-homogenous staining pattern shown by the antibody. This is likely a consequence of the larger antibody being less efficient at tumour penetration (Bannas et al. 2015).

Affimers have recently been used to target VEGF receptor 2 (VEGFR2), a key protein in blood vessel formation in tumours (Tiede et al. 2017). In histochemical staining, Affimers showed a similar staining pattern to but greater sensitivity than a commercially available anti-VEGFR2 antibody. Again, one proposal for this enhanced sensitivity is an improved ability to penetrate tissues due to the smaller size of the Affimer. In the same report, Affimers that target Tenascin C (TNC) were also shown to be effective in histochemistry techniques. Staining patterns were similar to those observed by an anti-TNC antibody, albeit with slightly reduced sensitivity in this case, but again demonstrating the utility of Affimers as reagents for the detection of tumour biomarkers in tissue (Tiede et al. 2017).

Of course, to make these types of reagents more useful to the wider scientific community, at least at this stage of their development, it might be appropriate to generate them as Fc fusions, thereby directly replacing antibody binding without the need to change current detection protocols.

\section{Alternative binding reagents for tumour imaging in vivo}

Although the detection of cancer biomarkers in tissue samples is useful for predicting prognosis and identifying the treatment path, the ability to image tumours in vivo and non-invasively is emerging as an important tool in cancer diagnosis (Stern et al. 2013; Vazquez-Lombardi et al. 2015). The smaller size and lack of $\mathrm{Fc}$ region of these alternative reagents enables much greater tumour penetration whilst also allowing rapid clearance from surrounding tissues, thus enhancing both the sensitivity and specificity of visualisation (Cuesta et al. 2009; Stern et al. 2013; Luo et al. 2015).

The diagnostic strategy currently employed for the detection of prostate cancer suffers from a low cancer detection rate and, consequently, more specific detection tools are required (Babaian et al. 2000). A number of antibody alternative reagents targeting prostate-specific membrane antigen (PSMA), a prostate cancer biomarker, have been developed (Chatalic et al. 2015; Han et al. 2016, Mazzocco et al. 2016). Their ability to recognise an extracellular epitope on PSMA has enabled the development of tests for use against viable tissues. This represents a marked improvement on currently approved monoclonal antibodies such as ProstaScint, which recognises an intracellular epitope on PSMA, thus limiting staining to necrotic tissues (Bander 2006; Chatalic et al. 2015; Barinka et al. 2016). Using an $\mathrm{ScFv}$ to target PSMA has improved diagnostic capabilities through reduced background labelling of endogenous Fc receptors in surrounding tissues (He et al. 2010; Mazzocco et al. 2016). Nanobodies and anticalins have shown similar promise in targeting PSMA, displaying good tumour targeting and rapid blood clearance (Chatalic et al. 2015; Barinka et al. 2016).

As discussed above, HER-2 has been targeted by a number of binding proteins. The success of antibody alternatives as HER-2 imaging tools in vivo has been highlighted by studies conducted using DARPins and Nanobodies. Increased sensitivity and lower background has been observed when imaging HER-2 and epidermal growth factor receptor (EGFR) biomarkers (Mortimer et al. 2014). The reduced off-target effects of Nanobodies are evidenced by their much faster clearance rates from non-specific tissues compared to monoclonal antibodies. The radiolabelled HER-2-targeting monoclonal antibody Trastuzumab (Delaney 1999) and the EGFR-targeting antibody Cetuximab (Prewett et al. 1996), both clinically approved, clear very slowly from non-specific tissues $(>24 \mathrm{~h})$. By comparison, the anti-EGFR Nanobody clears within 45 min of administration (Kruwel et al. 2016). Affimers have also been demonstrated for use as ex vivo imaging tools for the detection of tumour biomarkers (Tiede et al. 2017). The reduced circulation time and more rapid tumour penetration afforded by smaller binding proteins compared to antibodies provides the potential for a faster and timelier imaging procedure and thus should reduce patient time in hospital. Another approach with promise for in vivo tumour imaging involves dye-conjugated Affimers that have been used in Förster resonance transfer (FRET) experiments (Conway et al. 2014; Wang et al. 2017b).

The ability to use alternative-binding proteins to detect cancer biomarkers, as outlined in Table 1, has led researchers to attempt to develop their therapeutic potential by combining tumour detection with treatment, a field termed theranostics. Radionuclide-labelled antibodies have previously been explored for use in radio immunotherapy (RIT), a technique that exploits a tumour-targeting molecule to act as a vehicle for the transport of cytotoxic compounds to the tumour. Thirteen monoclonal antibodies are currently approved by the FDA for use in RIT, with the majority targeting blood-borne carcinomas (Reichert 2014; Ecker et al. 2015). Monoclonal antibodies that target cancers originating from epithelial tissues have so far been less successful (Weiner and Adams 2000) because of their slow diffusion rate to their target site due to their size. The improved tumour penetration and faster tissue clearance linked to smaller binding reagents has led to a number of efforts to use them in RIT, alternatively called targeted radionuclide therapy (TRNT). The use of Nanobodies in TRNT has been shown for the combined detection and therapy of human growth factor-expressing cancers (Vosjan et al. 
Table 1 Antibody alternatives for use as in vivo tumour imaging tools

\begin{tabular}{|c|c|c|c|}
\hline Reagent & Target $^{\mathrm{a}}$ & Tumour-association & Reference \\
\hline \multicolumn{4}{|l|}{ Nanobody } \\
\hline 8B6, 7C12, 7D12 & EGFR & Epidermoid and prostate & $\begin{array}{l}\text { Huang et al. 2008; } \\
\text { Gainkam et al. 2011; } \\
\text { Oliveira et al. 2012; } \\
\text { Kruwel et al. } 2016\end{array}$ \\
\hline 2Rs15d, 11A4 & HER-2 & Colon, breast and ovarian & $\begin{array}{l}\text { Vaneycken et al. 2011; } \\
\quad \text { Xavier et al. } 2013\end{array}$ \\
\hline $1 \mathrm{E} 2,6 \mathrm{E} 10$ & HGF & Glioblastoma & Vosjan et al. 2012 \\
\hline$\alpha-M M R$ & MMR & $\begin{array}{l}\text { Mammary adenocarcinoma, } \\
\text { Lewis lung carcinoma }\end{array}$ & Movahedi et al. 2012 \\
\hline CEA1 & CEA & Colon & Vaneycken et al. 2010 \\
\hline JVZ-007 & PSMA & Prostate & Chatalic et al. 2015 \\
\hline \multicolumn{4}{|l|}{ DARPin } \\
\hline (HE)3-G3 & HER-2 & Colon, breast and ovarian & $\begin{array}{l}\text { Mironova et al. 2014; } \\
\text { Goldstein et al. } 2015\end{array}$ \\
\hline \multicolumn{4}{|l|}{ Monobody } \\
\hline E1 & hEphA2 & Lung, breast and colon & Park et al. 2015 \\
\hline \multicolumn{4}{|l|}{ Anticalin } \\
\hline PRS-110 & HGFR & Various & $\begin{array}{l}\text { Terwisscha van Scheltinga } \\
\text { et al. } 2014\end{array}$ \\
\hline PRS-050 & VEGF-A & Various & Meier et al. 2014 \\
\hline A3 & PSMA & Prostate & Barinka et al. 2016 \\
\hline \multicolumn{4}{|l|}{ Affibody } \\
\hline ABY-025 & HER-2 & Colon, breast and ovarian & Sandberg et al. 2017 \\
\hline affiFAP & EGFR & Epidermoid and prostate & Wang et al. 2017a \\
\hline \multirow[t]{2}{*}{ ZHPV16E7384 } & $\begin{array}{l}\text { HPV16 } \\
\text { E6/E7 }\end{array}$ & Cervical & Xue et al. 2016 \\
\hline & CAIX & Renal & Garousi et al. 2016 \\
\hline 99mTc-ZIGFR:4551-GGGC & IGF-1R & Various & Mitran et al. 2015 \\
\hline HEHEHE-z08698-NOTA & PDGFR $\beta$ & Various & Rosestedt et al. 2015 \\
\hline \multicolumn{4}{|l|}{ Affimer } \\
\hline Anti-TNC Affimer & $\mathrm{TNC}$ & Various & Tiede et al. 2017 \\
\hline
\end{tabular}

${ }^{\text {a } E G F R ~ e p i d e r m a l ~ g r o w t h ~ f a c t o r ~ r e c e p t o r, ~} H E R-2$ human epidermal growth factor receptor-2, $H G F$ hepatocyte growth factor, $M M R$ macrophage mannose receptor, CEA carcinoembryonic antigen, PSMA prostate specific membrane antigen, $h E p h A 2$ human eryhoropoietin-producing hepatocellular A2, HGFR hepatocyte growth factor receptor, $V E G F-A$ vascular endothelial growth factor A, HPV16 E6/E7 human papillomavirus 16 E6 and E7 oncoproteins, $C A I X$ carbonic anhydrase $9, I G F-1 R$ insulin-like growth factor 1 receptor, $P D G F R \beta$ platelet-derived growth factor beta, $T N C$ tenascin $\mathrm{C}$
2012). Additionally, the Nanobody previously described for the detection of HER-2 has been conjugated to the radio lanthanide, lutetium-177, for this purpose (D'Huyvetter et al. 2014). Affibodies are another reagent class used for TRNT for the treatment of HER-2 disposed cancers, with lutetium177-tagged anti-HER-2 Affibodies demonstrating remarkable inhibition of tumour formation (Tolmachev et al. 2007).

Despite promising preliminary data for the use of antibody alternatives in TRNT, issues surrounding renal accumulation of radioactively labelled proteins requires further study (Gainkam et al. 2011; Vosjan et al. 2012). In the meantime, one possible approach is their use in pre-targeting, i.e. the targeting of pre-tagged binding reagents to a tumour location prior to the administration of radionuclides able to recognise the tag (Honarvar et al. 2016). An alternative proposal is the fusion of binding reagents to larger proteins to extend halflife; however this approach may result in further problems by causing the toxic compounds to accumulate in different tissues (Vosjan et al. 2012).

\section{Use of antibody alternatives as fluorescent imaging probes}

Fluorescent labelling of antibodies is a common approach for the detection and localisation of proteins in fixed cells. A 
major advantage of non-antibody binding proteins is their ability to be engineered at specific sites for site-directed modifications. In this context, the addition of a single cysteine residue to multiple non-antibody binding proteins, including Affimers, has allowed the site-specific addition of a fluorophore and alternative labels (Fisher et al. 2015; Tiede et al. 2017). Fluorescently labelled Affimers have been used to detect an antigen of herpesvirus of turkeys in infected cells lines, as well as in cell imaging by the fluorescent detection of TRPV1, a ligand-activated non-selective calcium-permeant cation channel (Tiede et al. 2017). In this study, live cells were incubated with an Affimer, and post-fixation localisation of the Affimer was detected using an antibody to a fusion tag; in addition co-localisation was observed with an anti-TRPV1 antibody. A further useful property of these reagents is their ability to function in the cytosol, thereby enabling live cell imaging. Nanobodies have exploited this property to visualise cytokeratin-B and lamin Dm0 in their dynamic states (Rothbauer et al. 2006), and a Nanobody raised against a HIV-1 precursor protein has enabled the observation of viral particle assembly in real-time (Helma et al. 2012).

In conventional fluorescence microscopy, spatial resolution is limited by the wavelength of light to approximately $200 \mathrm{~nm}$ at best, as discovered by Abbe (Abbe 1873). In the last few years, various approaches have been developed to overcome this limit, collectively termed as 'super-resolution' light microscopy (Evanko 2009; Patterson 2009; Galbraith and Galbraith 2011). In particular, single molecule localisation microscopy (SMLM) techniques, such as PALM (photoactivated localisation microscopy), STORM (stochastic optical reconstruction microscopy) and dSTORM (direct STORM), can localise the positions of single fluorophores with very high accuracy, providing resolutions of approximately $20 \mathrm{~nm}$. PALM uses genetically encoded fluorescent proteins (Betzig et al. 2006), while STORM (Rust et al. 2006) and dSTORM (Heilemann et al. 2008) use fluorescently labelled antibodies.

The best localisation precision tends to be obtained using synthetic dyes rather than fluorescent proteins because dyes emit higher numbers of photons and the localisation precision depends on the number of photons collected (Moerner 2012). However, this approach is limited by the fact that the dyes are conjugated to antibodies and thus are placed some distance away from the target protein. This means that the localisation accuracy is limited by the size of the antibody. In traditional immunofluorescence techniques, in which both a targetspecific primary and a secondary detection antibody are used, the dye can be placed as far away as approximately $30 \mathrm{~nm}$ from the intended target. This distance is referred to as 'linkage error'. Even directly conjugating the dye to a primary antibody ( $150 \mathrm{kDa}$; approx. $10 \mathrm{~nm}$ in size) still results in a linkage error of approximately $10 \mathrm{~nm}$ (Ries et al. 2012), and there may be multiple fluorophores per antibody. Whilst not important for most diffraction-limited immunofluorescence experiments, in super-resolution approaches this limitation significantly reduces the potential resolving power. The small size of alternative binding reagents reduces this linkage error, making these reagents particularly attractive for use in superresolution microscopy.

SMLM approaches have begun to exploit the small size of Nanobodies, for example the anti-green fluorescent protein (GFP) Nanobody (13 kDa, approx. $2 \mathrm{~nm}$ in size) used to target GFP-fusion proteins reduced the linkage error to approximatley $2 \mathrm{~nm}$ (Ries et al. 2012). Similar results have been obtained using Nanobodies against nuclear pore complex proteins (Pleiner et al. 2015). Nanobodies have also been used in DNA-PAINT (DNA-points accumulation in nanoscale topography) (Jungmann et al. 2010, 2014; Agasti et al. 2017). The anti-HER-2 Affibody has also shown promise in superresolution microscopy, enabling visualisation of the intra- and intercellular distribution patterns of HER-2 in over-expressing cancer cells (Peckys et al. 2015).

The small size of Affimers (approx. 10-12 kDa, approx. $2 \mathrm{~nm}$ ), similar to that of Nanobodies, and the ability to specifically label certain sites makes them useful tools in superresolution microscopy. Affimers have recently been obtained that specifically bind to tubulin and have been used in dSTORM [with both total internal reflection fluorescence (TIRF) and three-dimensional techniques]. Interestingly, the Affimer labels interphase microtubules in a similar way to a widely used antibody. In addition, the Affimer labels the central region of the cytokinetic furrow, a region from which antibodies are usually excluded owing to the density of tubulin in this region, highlighting a further advantage of using smaller probes. HER-4 Affimers have also demonstrated their value in single molecule tracking (Tiede et al. 2017).

\section{Conclusion}

After many years of antibodies dominating molecular recognition techniques in biology, the field now has the ability to use alternatives to move away from the reliance on animal-produced reagents. Over 50 non-antibody scaffolds with target recognition capabilities have been developed that provide a number of advantages over traditional antibodies. In addition to being produced without the use of animals, these non-antibody scaffolds demonstrate a higher stability and can be produced as recombinant proteins in E. coli. Their smaller size is particularly useful for imaging targets for two reasons. First, they penetrate tissues and can access epitopes in densely packed subcellular structures of cells more readily than antibodies, an advantage for both imaging tumours and in 'super-resolution' microscopy. Second, they place the fluorophore closer to the target of interest, providing an 
increased spatial resolution in 'super-resolution' approaches. We anticipate that such antibody alternatives will become widely used in a range of biological and medical imaging applications.

\section{Compliance with ethical standards}

Licencing Affimers are licenced to Avacta Life Sciences Ltd. (Wetherby, UK).

Conflict of interest R. Bedford declares that he has no conflicts of interest. C. Tiede declares that he has no conflicts of interest. R. Hughes declares that she has no conflicts of interest. A. Curd declares that he has no conflicts of interest. M.J. McPherson declares that he has no conflicts of interest. M. Peckham declares that she has no conflicts of interest. D.C.Tomlinson declares that he has no conflicts of interest.

Ethical approval This article does not contain any studies with human participants or animals performed by any of the authors.

Open Access This article is distributed under the terms of the Creative Commons Attribution 4.0 International License (http:// creativecommons.org/licenses/by/4.0/), which permits unrestricted use, distribution, and reproduction in any medium, provided you give appropriate credit to the original author(s) and the source, provide a link to the Creative Commons license, and indicate if changes were made.

\section{References}

Abbe E (1873) Beitrage zur Theorie der Microscopie und der Microscopischen Wahrnehmung. Arch Mikrosk Anat 9:413-468

Agasti SS, Wang Y, Schueder F, Sukumar A, Jungmann R, Yin P (2017) DNA-barcoded labeling probes for highly multiplexed exchangePAINT imaging. Chem Sci 8:3080-3091. doi:10.1039/c6sc05420j

Arrata I, Barnard A, Tomlinson DC, Wilson AJ (2017) Interfacing native and non-native peptides: using Affimers to recognise alpha-helix mimicking foldamers. Chem Commun (Camb) 53:2834-2837. doi:10.1039/c6cc09395g

Babaian RJ, Toi A, Kamoi K, Troncoso P, Sweet J, Evans R, Johnston D, Chen M (2000) A comparative analysis of sextant and an extended 11-core multisite directed biopsy strategy. J Urol 163:152-157

Bander NH (2006) Technology insight: monoclonal antibody imaging of prostate cancer. Nat Clin Pract Urol 3:216-225. doi:10.1038/ ncpuro0452

Bannas P, Lenz A, Kunick V, Fumey W, Rissiek B, Schmid J, Haag F, Leingartner A, Trepel M, Adam G, Koch-Nolte F (2015) Validation of nanobody and antibody based in vivo tumor xenograft NIRFimaging experiments in mice using ex vivo flow cytometry and microscopy. J Vis Exp:e52462. doi:10.3791/52462

Barinka C, Ptacek J, Richter A, Novakova Z, Morath V, Skerra A (2016) Selection and characterization of Anticalins targeting human prostate-specific membrane antigen (PSMA). Protein Eng Des Sel 29:105-115. doi:10.1093/protein/gzv065

Better M, Chang CP, Robinson RR, Horwitz AH (1988) Escherichia coli secretion of an active chimeric antibody fragment. Science 240 : 1041-1043

Betzig E, Patterson GH, Sougrat R, Lindwasser OW, Oleych S, Bonifacino JS, Davidson MW, Lippincott-Schwartz J, Hess HF (2006) Imaging intracellular fluorescent proteins at nanometer resolution. Science 313:1642-1645. doi:10.1126/science.1127344
Bordeaux J, Welsh A, Agarwal S, Killiam E, Baquero M, Hanna J, Anagnostou V, Rimm D (2010) Antibody validation. BioTechniques 48:197-209. doi:10.2144/000113382

Bouchelouche K, Choyke PL, Capala J (2010) Prostate specific membrane antigen - a target for imaging and therapy with radionuclides. Discov Med 9:55-61

Bradbury A, Pluckthun A (2015) Reproducibility: standardize antibodies used in research. Nature 518:27-29. doi:10.1038/518027a

Chatalic KL, Veldhoven-Zweistra J, Bolkestein M, Hoeben S, Koning GA, Boerman OC, de Jong M, van Weerden WM (2015) A novel (1)(1)(1)in-Labeled anti-prostate-specific membrane antigen Nanobody for targeted SPECT/CT imaging of prostate cancer. J Nucl Med 56:1094-1099. doi:10.2967/jnumed.115.156729

Conway JR, Carragher NO, Timpson P (2014) Developments in preclinical cancer imaging: innovating the discovery of therapeutics. Nat Rev Cancer 14:314-328. doi:10.1038/nrc3724

Cuesta AM, Sanchez-Martin D, Sanz L, Bonet J, Compte M, Kremer L, Blanco FJ, Oliva B, Alvarez-Vallina L (2009) In vivo tumor targeting and imaging with engineered trivalent antibody fragments containing collagen-derived sequences. PLoS One 4:e5381. doi:10. 1371/journal.pone.0005381

Daley LP, Kutzler MA, Bennett BW, Smith MC, Glaser AL, Appleton JA (2010) Effector functions of camelid heavy-chain antibodies in immunity to West Nile virus. Clin Vaccine Immunol 17:239-246. doi: 10.1128/CVI.00421-09

Delaney P (1999) HER-2: the making of Herceptin, a revolutionary treatment for breast cancer. J Natl Cancer Inst 91:1329-1330. doi:10. 1093/jnci/91.15.1329

D'Huyvetter M, Vincke C, Xavier C, Aerts A, Impens N, Baatout S, De Raeve H, Muyldermans S, Caveliers V, Devoogdt N, Lahoutte T (2014) Targeted radionuclide therapy with a $177 \mathrm{Lu}$-labeled antiHER2 nanobody. Theranostics 4:708-720. doi:10.7150/thno.8156

Ecker DM, Jones SD, Levine HL (2015) The therapeutic monoclonal antibody market. MAbs 7:9-14. doi:10.4161/19420862.2015. 989042

Evanko D (2009) Primer: fluorescence imaging under the diffraction limit. Nat Methods 6:19-20

Fisher MJ, Williamson DJ, Burslem GM, Plante JP, Manfield IW, Tiede C, Ault JR, Stockley PG, Plein S, Maqbool A, Tomlinson DC, Foster R, Warriner SL, Bon RS (2015) Trivalent Gd-DOTA reagents for modification of proteins. RSC Adv 5:96194-96200. doi:10. $1039 / \mathrm{c} 5 \mathrm{ra} 20359 \mathrm{~g}$

Gainkam LO, Caveliers V, Devoogdt N, Vanhove C, Xavier C, Boerman O, Muyldermans S, Bossuyt A, Lahoutte T (2011) Localization, mechanism and reduction of renal retention of technetium- $99 \mathrm{~m}$ labeled epidermal growth factor receptor-specific nanobody in mice. Contrast Media Mol Imaging 6:85-92. doi:10.1002/cmmi.408

Galbraith CG, Galbraith JA (2011) Super-resolution microscopy at a glance. J Cell Sci 124:1607-1611. doi:10.1242/jcs.080085

Garousi J, Honarvar H, Andersson KG, Mitran B, Orlova A, Buijs J, Lofblom J, Frejd FY, Tolmachev V (2016) Comparative evaluation of Affibody molecules for radionuclide imaging of in vivo expression of carbonic Anhydrase IX. Mol Pharm 13:3676-3687. doi:10. 1021/acs.molpharmaceut.6b00502

Gebauer M, Skerra A (2012) Anticalins small engineered binding proteins based on the lipocalin scaffold. Methods Enzymol 503:157188. doi:10.1016/B978-0-12-396962-0.00007-0

Goldstein R, Sosabowski J, Livanos M, Leyton J, Vigor K, Bhavsar G, Nagy-Davidescu G, Rashid M, Miranda E, Yeung J, Tolner B, Pluckthun A, Mather S, Meyer T, Chester K (2015) Development of the designed ankyrin repeat protein (DARPin) G3 for HER2 molecular imaging. Eur J Nucl Med Mol Imaging 42:288-301. doi:10.1007/s00259-014-2940-2

Hamers-Casterman C, Atarhouch T, Muyldermans S, Robinson G, Hamers C, Songa EB, Bendahman N, Hamers R (1993) Naturally 
occurring antibodies devoid of light chains. Nature 363:446-448. doi:10.1038/363446a0

Han D, Wu J, Han Y, Wei M, Han S, Lin R, Sun Z, Yang F, Jiao D, Xie P, Zhang L, Yang AG, Zhao A, Wen W, Qin W (2016) A novel antiPSMA human scFv has the potential to be used as a diagnostic tool in prostate cancer. Oncotarget 7:59471-59481. doi:10.18632/ oncotarget.10697

He J, Wang Y, Feng J, Zhu X, Lan X, Iyer AK, Zhang N, Seo Y, VanBrocklin HF, Liu B (2010) Targeting prostate cancer cells in vivo using a rapidly internalizing novel human single-chain antibody fragment. J Nucl Med 51:427-432. doi:10.2967/jnumed.109. 069492

Heilemann M, van de Linde S, Schuttpelz M, Kasper R, Seefeldt B, Mukherjee A, Tinnefeld P, Sauer M (2008) Subdiffractionresolution fluorescence imaging with conventional fluorescent probes. Angew Chem Int Ed Eng 47:6172-6176. doi:10.1002/ anie. 200802376

Helma J, Schmidthals K, Lux V, Nuske S, Scholz AM, Krausslich HG, Rothbauer U, Leonhardt H (2012) Direct and dynamic detection of HIV-1 in living cells. PLoS One 7:e50026. doi:10.1371/journal. pone.0050026

Hey T, Fiedler E, Rudolph R, Fiedler M (2005) Artificial, non-antibody binding proteins for pharmaceutical and industrial applications. Trends Biotechnol 23:514-522. doi:10.1016/j.tibtech.2005.07.007

Hoffmann T, Stadler LK, Busby M, Song Q, Buxton AT, Wagner SD, Davis JJ, Ko Ferrigno P (2010) Structure-function studies of an engineered scaffold protein derived from stefin a. I: development of the SQM variant. Protein Eng Des Sel 23:403-413. doi:10. 1093/protein/gzq012

Holliger P, Hudson PJ (2005) Engineered antibody fragments and the rise of single domains. Nat Biotechnol 23:1126-1136. doi:10.1038/ nbt1142

Honarvar H, Westerlund K, Altai M, Sandstrom M, Orlova A, Tolmachev V, Karlstrom AE (2016) Feasibility of Affibody molecule-based PNA-mediated radionuclide pretargeting of malignant tumors. Theranostics 6:93-103. doi:10.7150/thno.12766

Howat WJ, Lewis A, Jones P, Kampf C, Ponten F, van der Loos CM, Gray N, Womack C, Warford A (2014) Antibody validation of immunohistochemistry for biomarker discovery: recommendations of a consortium of academic and pharmaceutical based histopathology researchers. Methods 70:34-38. doi:10.1016/j.ymeth.2014.01.018

Huang L, Gainkam LO, Caveliers V, Vanhove C, Keyaerts M, De Baetselier P, Bossuyt A, Revets H, Lahoutte T (2008) SPECT imaging with $99 \mathrm{mTc}$-labeled EGFR-specific nanobody for in vivo monitoring of EGFR expression. Mol Imaging Biol 10:167-175. doi:10.1007/s11307-008-0133-8

Jungmann R, Steinhauer C, Scheible M, Kuzyk A, Tinnefeld P, Simmel FC (2010) Single-molecule kinetics and super-resolution microscopy by fluorescence imaging of transient binding on DNA origami. Nano Lett 10:4756-4761. doi:10.1021/n1103427w

Jungmann R, Avendano MS, Woehrstein JB, Dai M, Shih WM, Yin P (2014) Multiplexed 3D cellular super-resolution imaging with DNA-PAINT and exchange-PAINT. Nat Methods 11:313-318. doi:10.1038/nmeth.2835

Kawe M, Forrer P, Amstutz P, Pluckthun A (2006) Isolation of intracellular proteinase inhibitors derived from designed ankyrin repeat proteins by genetic screening. J Biol Chem 281:40252-40263. doi:10. 1074/jbc.M602506200

Kohler G, Milstein C (1975) Continuous cultures of fused cells secreting antibody of predefined specificity. Nature 256:495-497

Koide A, Bailey CW, Huang X, Koide S (1998) The fibronectin type III domain as a scaffold for novel binding proteins. J Mol Biol 284: 1141-1151. doi:10.1006/jmbi.1998.2238

Koide A, Wojcik J, Gilbreth RN, Hoey RJ, Koide S (2012) Teaching an old scaffold new tricks: monobodies constructed using alternative surfaces of the FN3 scaffold. J Mol Biol 415:393-405. doi:10.1016/ j.jmb.2011.12.019

Koutsoumpeli E, Tiede C, Murray J, Tang A, Bon RS, Tomlinson DC, Johnson S (2017) Antibody mimetics for the detection of small organic compounds using a quartz crystal microbalance. Anal Chem 89:3051-3058. doi:10.1021/acs.analchem.6b04790

Kruwel T, Nevoltris D, Bode J, Dullin C, Baty D, Chames P, Alves F (2016) In vivo detection of small tumour lesions by multi-pinhole SPECT applying a (99m)Tc-labelled nanobody targeting the epidermal growth factor receptor. Sci Rep 6:21834. doi:10.1038/ srep21834

Kyle HF, Wickson KF, Stott J, Burslem GM, Breeze AL, Tiede C, Tomlinson DC, Warriner SL, Nelson A, Wilson AJ, Edwards TA (2015) Exploration of the HIF-1alpha/p300 interface using peptide and Adhiron phage display technologies. Mol BioSyst 11:2738 2749. doi:10.1039/c5mb00284b

Lofblom J, Feldwisch J, Tolmachev V, Carlsson J, Stahl S, Frejd FY (2010) Affibody molecules: engineered proteins for therapeutic, diagnostic and biotechnological applications. FEBS Lett 584:2670 2680. doi:10.1016/j.febslet.2010.04.014

Luo H, Hernandez R, Hong H, Graves SA, Yang Y, England CG, Theuer CP, Nickles RJ, Cai W (2015) Noninvasive brain cancer imaging with a bispecific antibody fragment, generated via click chemistry. Proc Natl Acad Sci USA 112:12806-12811. doi:10.1073/pnas. 1509667112

Mazzocco C, Fracasso G, Germain-Genevois C, Dugot-Senant N, Figini M, Colombatti M, Grenier N, Couillaud F (2016) In vivo imaging of prostate cancer using an anti-PSMA scFv fragment as a probe. Sci Rep 6:23314. doi:10.1038/srep23314

Meier R, Braren R, Kosanke Y, Bussemer J, Neff F, Wildgruber M, Schwarzenbock S, Frank A, Haller B, Hohlbaum AM, Schwaiger M, Gille H, Rummeny EJ, Beer AJ (2014) Multimodality multiparametric imaging of early tumor response to a novel antiangiogenic therapy based on anticalins. PLoS One 9:e94972. doi:10.1371/journal.pone.0094972

Mironova KE, Chernykh ON, Ryabova AV, Stremovskiy OA, Proshkina GM, Deyev SM (2014) Highly specific hybrid protein DARPinmCherry for fluorescent visualization of cells overexpressing tumor marker HER2/neu. Biochemistry (Mosc) 79:1391-1396. doi:10. 1134/S0006297914120141

Mitran B, Altai M, Hofstrom C, Honarvar H, Sandstrom M, Orlova A, Tolmachev V, Graslund T (2015) Evaluation of 99mTc-Z IGF1R: 4551-GGGC affibody molecule, a new probe for imaging of insulinlike growth factor type 1 receptor expression. Amino Acids 47:303315. doi:10.1007/s00726-014-1859-z

Moebius U, Feuerer W, Fenzl E, van Swelm R, Swinkels DW, Hohlbaum A (2015) A phase I study investigating the safety, tolerability, pharmacokinetics and pharmacodynamic activity of the hepcidin antagonist PRS-080\#022. Results from a randomized, placebo controlled, double-blind study following single administration to healthy subjects. Blood 126:536

Moerner WE (2012) Microscopy beyond the diffraction limit using actively controlled single molecules. J Microsc 246(3):213-220. doi: 10.1111/j.1365-2818-2012-03600.x

Mortimer JE, Bading JR, Colcher DM, Conti PS, Frankel PH, Carroll MI, Tong S, Poku E, Miles JK, Shively JE, Raubitschek AA (2014) Functional imaging of human epidermal growth factor receptor 2positive metastatic breast cancer using (64)cu-DOTA-trastuzumab PET. J Nucl Med 55:23-29. doi:10.2967/jnumed.113.122630

Movahedi K, Schoonooghe S, Laoui D, Houbracken I, Waelput W, Breckpot K, Bouwens L, Lahoutte T, De Baetselier P, Raes G, Devoogdt N, Van Ginderachter JA (2012) Nanobody-based targeting of the macrophage mannose receptor for effective in vivo imaging of tumor-associated macrophages. Cancer Res 72:41654177. doi:10.1158/0008-5472.CAN-11-2994 
Muyldermans S (2001) Single domain camel antibodies: current status. J Biotechnol 74:277-302

Nelson AL, Reichert JM (2009) Development trends for therapeutic antibody fragments. Nat Biotechnol 27:331-337. doi:10.1038/ nbt0409-331

Nguyen VK, Desmyter A, Muyldermans S (2001) Functional heavychain antibodies in Camelidae. Adv Immunol 79:261-296

Nord K, Gunneriusson E, Ringdahl J, Stahl S, Uhlen M, Nygren PA (1997) Binding proteins selected from combinatorial libraries of an alpha-helical bacterial receptor domain. Nat Biotechnol 15:772777. doi:10.1038/nbt0897-772

Oliveira S, van Dongen GA, Stigter-van Walsum M, Roovers RC, Stam JC, Mali W, van Diest PJ, van Bergen en Henegouwen PM (2012) Rapid visualization of human tumor xenografts through optical imaging with a near-infrared fluorescent anti-epidermal growth factor receptor nanobody. Mol Imaging 11:33-46

Orlova A, Feldwisch J, Abrahmsen L, Tolmachev V (2007) Update: affibody molecules for molecular imaging and therapy for cancer. Cancer Biother Radiopharm 22:573-584. doi:10.1089/cbr.2006. 004-U

Park SH, Park S, Kim DY, Pyo A, Kimura RH, Sathirachinda A, Choy HE, Min JJ, Gambhir SS, Hong Y (2015) Isolation and characterization of a Monobody with a fibronectin domain III scaffold that specifically binds EphA2. PLoS One 10:e132976. doi:10.1371/ journal.pone. 0132976

Patterson GH (2009) Fluorescence microscopy below the diffraction limit. Semin Cell Dev Biol 8:886-893. doi:10.1016/j.semcdb.2009.08. 006

Peckys DB, Korf U, de Jonge N (2015) Local variations of HER2 dimerization in breast cancer cells discovered by correlative fluorescence and liquid electron microscopy. Sci Adv 1:e1500165. doi:10.1126/ sciadv. 1500165

Pleiner T, Bates M, Trakhanov S, Lee CT, Schliep JE, Chug H, Bohning M, Stark H, Urlaub H, Gorlich D (2015) Nanobodies: site-specific labeling for super-resolution imaging, rapid epitope-mapping and native protein complex isolation. elife 4:e11349. doi:10.7554/ eLife. 11349

Prewett M, Rockwell P, Rockwell RF, Giorgio NA, Mendelsohn J, Scher HI, Goldstein NI (1996) The biologic effects of C225, a chimeric monoclonal antibody to the EGFR, on human prostate carcinoma. J Immunother Emphasis Tumor Immunol 19:419-427

Raina M, Sharma R, Deacon SE, Tiede C, Tomlinson D, Davies AG, McPherson MJ, Walti C (2015) Antibody mimetic receptor proteins for label-free biosensors. Analyst 140:803-810. doi:10.1039/ c4an01418a

Reichert JM (2014) Antibodies to watch in 2014. MAbs 6:5-14. doi:10. 4161/mabs. 27333

Ries J, Kaplan C, Platonova E, Eghlidi H, Ewers H (2012) A simple, versatile method for GFP-based super-resolution microscopy via nanobodies. Nat Methods 9:582-584. doi:10.1038/nmeth.1991

Roovers RC, van Dongen GA, van Bergen en Henegouwen PM (2007) Nanobodies in therapeutic applications. Curr Opin Mol Ther 9:327335

Rosestedt M, Andersson KG, Mitran B, Tolmachev V, Lofblom J, Orlova A, Stahl S (2015) Affibody-mediated PET imaging of HER3 expression in malignant tumours. Sci Rep 5:15226. doi:10.1038/ srep15226

Rothbauer U, Zolghadr K, Tillib S, Nowak D, Schermelleh L, Gahl A, Backmann N, Conrath K, Muyldermans S, Cardoso MC, Leonhardt $\mathrm{H}$ (2006) Targeting and tracing antigens in live cells with fluorescent nanobodies. Nat Methods 3:887-889. doi:10.1038/nmeth953

Rust MJ, Bates M, Zhuang X (2006) Sub-diffraction-limit imaging by stochastic optical reconstruction microscopy (STORM). Nat Methods 3:793-795

Sandberg D, Tolmachev V, Velikyan I, Olofsson H, Wennborg A, Feldwisch J, Carlsson J, Lindman H, Sorensen J (2017) Intra- image referencing for simplified assessment of HER2-expression in breast cancer metastases using the Affibody molecule ABY-025 with PET and SPECT. Eur J Nucl Med Mol Imaging 44(8):13371346. doi:10.1007/s00259-017-3650-3

Seidman AD, Berry D, Cirrincione C, Harris L, Muss H, Marcom PK, Gipson G, Burstein H, Lake D, Shapiro CL, Ungaro P, Norton L, Winer E, Hudis C (2008) Randomized phase III trial of weekly compared with every-3-weeks paclitaxel for metastatic breast cancer, with trastuzumab for all HER-2 overexpressors and random assignment to trastuzumab or not in HER-2 nonoverexpressors: final results of cancer and Leukemia group B protocol 9840. J Clin Oncol 26:1642-1649. doi:10.1200/JCO.2007.11.6699

Sha F, Salzman G, Gupta A, Koide S (2017) Monobodies and other synthetic binding proteins for expanding protein science. Protein Sci 26:910-924. doi:10.1002/pro.3148

Sharma R, Deacon SE, Nowak D, George SE, Szymonik MP, Tang AA, Tomlinson DC, Davies AG, McPherson MJ, Walti C (2016) Labelfree electrochemical impedance biosensor to detect human interleukin- 8 in serum with sub-pg/ml sensitivity. Biosens Bioelectron 80:607-613. doi:10.1016/j.bios.2016.02.028

Simeon R, Chen Z (2017) In vitro-engineered non-antibody protein therapeutics. Protein Cell. doi:10.1007/s13238-017-0386-6

Skerra A (2007) Alternative non-antibody scaffolds for molecular recognition. Curr Opin Biotechnol 18:295-304. doi:10.1016/j.copbio. 2007.04.010

Skerra A, Pluckthun A (1988) Assembly of a functional immunoglobulin fv fragment in Escherichia coli. Science 240:1038-1041

Skrlec K, Strukelj B, Berlec A (2015) Non-immunoglobulin scaffolds: a focus on their targets. Trends Biotechnol 33:408-418. doi:10.1016/ j.tibtech.2015.03.012

Slamon DJ, Clark GM, Wong SG, Levin WJ, Ullrich A, McGuire WL (1987) Human breast cancer: correlation of relapse and survival with amplification of the HER-2/neu oncogene. Science 235:177-182

Stahl A, Stumpp MT, Schlegel A, Ekawardhani S, Lehrling C, Martin G, Gulotti-Georgieva M, Villemagne D, Forrer P, Agostini HT, Binz HK (2013) Highly potent VEGF-A-antagonistic DARPins as antiangiogenic agents for topical and intravitreal applications. Angiogenesis 16:101-111. doi:10.1007/s10456-012-9302-0

Starzl TE, Fung JJ (1986) ORTHOCLONE OKT3 in treatment of Allografts rejected under cyclosporine-steroid therapy. Transplant Proc 18:937-941

Stern LA, Case BA, Hackel BJ (2013) Alternative non-antibody protein scaffolds for molecular imaging of cancer. Curr Opin Chem Eng 2: 425-432. doi:10.1016/j.coche.2013.08.009

Tamaskovic R, Simon M, Stefan N, Schwill M, Pluckthun A (2012) Designed ankyrin repeat proteins (DARPins) from research to therapy. Methods Enzymol 503:101-134. doi:10.1016/B978-0-12396962-0.00005-7

Taussig MJ, Stoevesandt O, Borrebaeck CA, Bradbury AR, Cahill D, Cambillau C, de Daruvar A, Dubel S, Eichler J, Frank R, Gibson TJ, Gloriam D, Gold L, Herberg FW, Hermjakob H, Hoheisel JD, Joos TO, Kallioniemi O, Koegl M, Konthur Z, Korn B, Kremmer E, Krobitsch S, Landegren U, van der Maarel S, McCafferty J, Muyldermans S, Nygren PA, Palcy S, Pluckthun A, Polic B, Przybylski M, Saviranta P, Sawyer A, Sherman DJ, Skerra A, Templin M, Ueffing M, Uhlen M (2007) ProteomeBinders: planning a European resource of affinity reagents for analysis of the human proteome. Nat Methods 4:13-17. doi:10.1038/nmeth0107-13

Terwisscha van Scheltinga AG, Lub-de Hooge MN, Hinner MJ, Verheijen RB, Allersdorfer A, Hulsmeyer M, Nagengast WB, Schroder CP, Kosterink JG, de Vries EG, Audoly L, Olwill SA (2014) In vivo visualization of MET tumor expression and anticalin biodistribution with the MET-specific anticalin 89Zr-PRS-110 PET tracer. J Nucl Med 55:665-671. doi:10.2967/jnumed.113.124941

Theurillat JP, Dreier B, Nagy-Davidescu G, Seifert B, Behnke S, ZurrerHardi U, Ingold F, Pluckthun A, Moch H (2010) Designed ankyrin 
repeat proteins: a novel tool for testing epidermal growth factor receptor 2 expression in breast cancer. Mod Pathol 23:1289-1297. doi:10.1038/modpathol.2010.103

Tiede C, Tang AA, Deacon SE, Mandal U, Nettleship JE, Owen RL, George SE, Harrison DJ, Owens RJ, Tomlinson DC, McPherson MJ (2014) Adhiron: a stable and versatile peptide display scaffold for molecular recognition applications. Protein Eng Des Sel 27:145155. doi:10.1093/protein/gzu007

Tiede C, Bedford R, Heseltine SJ, Smith G, Wijetunga I, Ross R, AlQallaf D, Roberts AP, Balls A, Curd A, Hughes RE, Martin H, Needham SR, Zanetti-Domingues LC, Sadigh Y, Peacock TP, Tang AA, Gibson N, Kyle H, Platt GW, Ingram N, Taylor T, Coletta LP, Manfield I, Knowles M, Bell S, Esteves F, Maqbool A, Prasad RK, Drinkhill M, Bon RS, Patel V, Goodchild SA, Martin-Fernandez M, Owens RJ, Nettleship JE, Webb ME, Harrison M, Lippiat JD, Ponnambalam S, Peckham M, Smith A, Ferrigno PK, Johnson M, McPherson MJ, Tomlinson DC (2017) Affimer proteins are versatile and renewable affinity reagents. eLife 6. doi:10.7554/eLife.24903

Tolmachev V, Orlova A, Pehrson R, Galli J, Baastrup B, Andersson K, Sandstrom M, Rosik D, Carlsson J, Lundqvist H, Wennborg A, Nilsson FY (2007) Radionuclide therapy of HER2-positive microxenografts using a 177Lu-labeled HER2-specific Affibody molecule. Cancer Res 67:2773-2782. doi:10.1158/0008-5472. CAN-06-1630

Van Audenhove I, Gettemans J (2016) Nanobodies as versatile tools to understand, diagnose, visualize and treat cancer. EBioMedicine 8: 40-48. doi:10.1016/j.ebiom.2016.04.028

van der Vegt B, de Bock GH, Bart J, Zwartjes NG, Wesseling J (2009) Validation of the 4B5 rabbit monoclonal antibody in determining Her2/neu status in breast cancer. Mod Pathol 22:879-886. doi:10. 1038/modpathol.2009.37

Vaneycken I, Govaert J, Vincke C, Caveliers V, Lahoutte T, De Baetselier P, Raes G, Bossuyt A, Muyldermans S, Devoogdt N (2010) In vitro analysis and in vivo tumor targeting of a humanized, grafted nanobody in mice using pinhole SPECT/micro-CT. J Nucl Med 51:1099-1106. doi:10.2967/jnumed.109.069823

Vaneycken I, Devoogdt N, Van Gassen N, Vincke C, Xavier C, Wernery U, Muyldermans S, Lahoutte T, Caveliers V (2011) Preclinical screening of anti-HER2 nanobodies for molecular imaging of breast cancer. FASEB J 25:2433-2446. doi:10.1096/fj.10-180331

Vazquez-Lombardi R, Phan TG, Zimmermann C, Lowe D, Jermutus L, Christ D (2015) Challenges and opportunities for non-antibody scaffold drugs. Drug Discov Today 20:1271-1283. doi:10.1016/j. drudis.2015.09.004
Vogel CL, Cobleigh MA, Tripathy D, Gutheil JC, Harris LN, Fehrenbacher L, Slamon DJ, Murphy M, Novotny WF, Burchmore M, Shak S, Stewart SJ, Press M (2002) Efficacy and safety of trastuzumab as a single agent in first-line treatment of HER2-overexpressing metastatic breast cancer. J Clin Oncol 20: 719-726. doi:10.1200/JCO.2002.20.3.719

Vogt M, Skerra A (2004) Construction of an artificial receptor protein ("anticalin") based on the human apolipoprotein D. Chembiochem 5:191-199. doi:10.1002/cbic.200300703

Vosjan MJ, Vercammen J, Kolkman JA, Stigter-van Walsum M, Revets H, van Dongen GA (2012) Nanobodies targeting the hepatocyte growth factor: potential new drugs for molecular cancer therapy. Mol Cancer Ther 11:1017-1025. doi:10.1158/1535-7163.MCT-110891

Wang RE, Zhang Y, Tian L, Cai W, Cai J (2013) Antibody-based imaging of HER-2: moving into the clinic. Curr Mol Med 13:1523-1537

Wang Y, Ballou B, Schmidt BF, Andreko S, St Croix CM, Watkins SC, Bruchez MP (2017a) Affibody-targeted fluorogen activating protein for in vivo tumor imaging. Chem Commun (Camb) 53:2001-2004. doi:10.1039/c6ec09137g

Wang W, Guo Y, Tiede C, Chen S, Kopytynski M, Kong Y, Kulak A, Tomlinson D, Chen R, McPherson M, Zhou D (2017b) Ultraefficient cap-exchange protocol to compact biofunctional quantum dots for sensitive ratiometric biosensing and cell imaging. ACS Appl Mater Interfaces 9:15232-15244. doi:10.1021/acsami. $6 \mathrm{~b} 13807$

Weiner LM, Adams GP (2000) New approaches to antibody therapy. Oncogene 19:6144-6151. doi:10.1038/sj.onc. 1204000

Wojcik J, Lamontanara AJ, Grabe G, Koide A, Akin L, Gerig B, Hantschel O, Koide S (2016) Allosteric inhibition of Bcr-Abl Kinase by high affinity Monobody inhibitors directed to the Src homology 2 (SH2)-Kinase Interface. J Biol Chem 291:8836-8847. doi:10.1074/jbc.M115.707901

Xavier C, Vaneycken I, D'Huyvetter M, Heemskerk J, Keyaerts M, Vincke C, Devoogdt N, Muyldermans S, Lahoutte T, Caveliers V (2013) Synthesis, preclinical validation, dosimetry, and toxicity of 68Ga-NOTA-anti-HER2 Nanobodies for iPET imaging of HER2 receptor expression in cancer. J Nucl Med 54:776-784. doi:10. 2967/jnumed.112.111021

Xue X, Wang B, Du W, Zhang C, Song Y, Cai Y, Cen D, Wang L, Xiong Y, Jiang P, Zhu S, Zhao KN, Zhang L (2016) Generation of affibody molecules specific for HPV16 E7 recognition. Oncotarget 7:7399574005. doi:10.18632/oncotarget.12174 